University of Montana

ScholarWorks at University of Montana

Numerical Terradynamic Simulation Group

Publications

Numerical Terradynamic Simulation Group

4-2015

\title{
Assimilation of Freeze-Thaw Observations into the NASA Catchment Land Surface Model
}

Leila Farhadi

Rolf H. Reichle

NASA

Gabrielle J. M. De Lannoy

John S. Kimball

University of Montana - Missoula

Follow this and additional works at: https://scholarworks.umt.edu/ntsg_pubs

Let us know how access to this document benefits you.

\section{Recommended Citation}

Farhadi, L., R. Reichle, G. De Lannoy, and J. Kimball, 2015: Assimilation of Freeze-Thaw Observations into the NASA Catchment Land Surface Model. J. Hydrometeor., 16, 730-743, doi: 10.1175/JHM-D-14-0065.1

This Article is brought to you for free and open access by the Numerical Terradynamic Simulation Group at ScholarWorks at University of Montana. It has been accepted for inclusion in Numerical Terradynamic Simulation Group Publications by an authorized administrator of ScholarWorks at University of Montana. For more information, please contact scholarworks@mso.umt.edu. 


\title{
Assimilation of Freeze-Thaw Observations into the NASA Catchment Land Surface Model
}

\author{
LEILA FARHADI \\ Global Modeling and Assimilation Office, NASA Goddard Flight Center, Greenbelt, Maryland, and Department of \\ Civil and Environmental Engineering, George Washington University, Washington, D.C. \\ ROLF H. REICHLE \\ Global Modeling and Assimilation Office, NASA Goddard Flight Center, Greenbelt, Maryland \\ GABRIËLle J. M. DE LANNOY \\ Global Modeling and Assimilation Office, and Universities Space Research Association, NASA Goddard Space \\ Flight Center, Greenbelt, Maryland \\ JOHN S. KIMBALL \\ Flathead Lake Biological Station, Division of Biological Sciences, University of Montana, Polson, Montana
}

(Manuscript received 31 March 2014, in final form 26 September 2014)

\begin{abstract}
The land surface freeze-thaw (F/T) state plays a key role in the hydrological and carbon cycles and thus affects water and energy exchanges and vegetation productivity at the land surface. In this study, an F/T assimilation algorithm was developed for the NASA Goddard Earth Observing System, version 5 (GEOS-5), modeling and assimilation framework. The algorithm includes a newly developed observation operator that diagnoses the landscape F/T state in the GEOS-5 Catchment land surface model. The F/T analysis is a rulebased approach that adjusts Catchment model state variables in response to binary F/T observations, while also considering forecast and observation errors. A regional observing system simulation experiment was conducted using synthetically generated F/T observations. The assimilation of perfect (error free) F/T observations reduced the root-mean-square errors (RMSEs) of surface temperature and soil temperature by $0.206^{\circ}$ and $0.061^{\circ} \mathrm{C}$, respectively, when compared to model estimates (equivalent to a relative RMSE reduction of $6.7 \%$ and $3.1 \%$, respectively). For a maximum classification error $\mathrm{CE}_{\max }$ of $10 \%$ in the synthetic $\mathrm{F} / \mathrm{T}$ observations, the F/T assimilation reduced the RMSE of surface temperature and soil temperature by $0.178^{\circ}$ and $0.036^{\circ} \mathrm{C}$, respectively. For $\mathrm{CE}_{\max }=20 \%$, the $\mathrm{F} / \mathrm{T}$ assimilation still reduces the RMSE of model surface temperature estimates by $0.149^{\circ} \mathrm{C}$ but yields no improvement over the model soil temperature estimates. The $\mathrm{F} / \mathrm{T}$ assimilation scheme is being developed to exploit planned F/T products from the NASA Soil Moisture Active Passive (SMAP) mission.
\end{abstract}

\section{Introduction}

Over one-third of the global land area undergoes a seasonal transition between predominantly frozen and nonfrozen conditions each year (Kim et al. 2011). This land surface freeze-thaw $(\mathrm{F} / \mathrm{T})$ transition is closely linked

\footnotetext{
Corresponding author address: Leila Farhadi, Dept. of Civil and Environmental Engineering, George Washington University, 801 22nd St., NW, Washington, DC 20052.

E-mail: lfarhadi@gwu.edu
}

to the timing and length of the vegetation growing season (e.g., Black et al. 2000; Grippa et al. 2005; Kimball et al. 2006), the seasonal evolution of land-atmosphere carbon dioxide $\left(\mathrm{CO}_{2}\right)$ exchange (Goulden et al. 1996), and the timing of seasonal snowmelt, soil thaw, and spring flood pulses (Kimball et al. 2001; Rawlins et al. 2005; Kane et al. 2008). The land surface $F / T$ state thus acts as a natural on/off switch for hydrological and biospheric processes over northern land areas and at high elevations where seasonal frozen temperatures represent a significant portion of the annual cycle (Kim et al. 2011). 
Studies show that the growing season, vegetation productivity, and land-atmosphere $\mathrm{CO}_{2}$ exchange patterns are shifting as a result of global warming (e.g., Randerson et al. 1999; Nemani et al. 2003). For example, Smith et al. (2004), McDonald et al. (2004), Kimball et al. (2006), Kim et al. (2012), and Wang et al. (2013) found consistency between these patterns and changes in seasonal $\mathrm{F} / \mathrm{T}$ dynamics observed by satellite microwave remote sensing. Thus, for more accurate modeling and prediction of land surface hydrological and biospheric processes, a good representation of the landscape $\mathrm{F} / \mathrm{T}$ state in land surface schemes is needed. Recent efforts to enhance $\mathrm{F} / \mathrm{T}$ modeling through improved and more expansive representation of permafrost include work on the Variable Infiltration Capacity model (VIC; Cherkauer et al. 2003), the Community Land Model (CLM; Lawrence et al. 2008, 2012), ORCHIDEE (Koven et al. 2009), the Joint UK Land Environment Simulator (JULES; Dankers et al. 2011), and the pan-Arctic water balance model (Rawlins et al. 2013).

Surface air temperature measurements from regional weather stations can provide an indication of the landscape F/T state. However, the limited coverage of global weather station networks, especially at higher latitudes and elevations, severely limits the capability for global monitoring and the ability to capture $\mathrm{F} / \mathrm{T}$ spatial and temporal patterns (Kim et al. 2011). Satellite observations of passive and active microwaves are well suited for characterizing the landscape $\mathrm{F} / \mathrm{T}$ state (Frolking et al. 1999; Bateni et al. 2013; Rautiainen et al. 2012, 2014). Lower-frequency ( $\leq 37 \mathrm{GHz}$ ) microwave observations vary significantly between frozen and thawed landscapes as a result of the strong sensitivity to contrasting dielectric properties.

A number of algorithms have been developed to detect the landscape $\mathrm{F} / \mathrm{T}$ state at $25-50-\mathrm{km}$ resolution using brightness temperature measurements from the Advanced Microwave Scanning Radiometer for the Earth Observing System (Zhao et al. 2011), the Scanning Multichannel Microwave Radiometer (Zuerndorfer and England 1992), the Special Sensor Microwave Imager (Zhang and Armstrong 2001), and the Soil Moisture and Ocean Salinity mission (Rautiainen et al. 2014). Similarly, radar backscatter data have been utilized in several studies for the detection of the land surface F/T state (Frolking et al. 1999; Kimball et al. 2001; Bartsch et al. 2011; see also section 2). The L-band $(1.4 \mathrm{GHz})$ radar observations from the Soil Moisture Active Passive (SMAP) mission (to be launched in early 2015) will provide a global classification of the $\mathrm{F} / \mathrm{T}$ state at a $3-\mathrm{km}$ spatial resolution and with a 3-day temporal fidelity (Entekhabi et al. 2010, 2014). The lower sensitivity to snow and vegetation of the L-band measurements compared to higher-frequency measurements should result in better detection of the landscape $\mathrm{F} / \mathrm{T}$ signal. Moreover, the $3-\mathrm{km}$ SMAP F/T product represents a considerable improvement in resolution compared to current radiometer $\mathrm{F} / \mathrm{T}$ products (e.g., Kim et al. 2012). See section 2 for more discussion.

The assimilation of remotely sensed $\mathrm{F} / \mathrm{T}$ retrievals into land surface models might improve the simulation of carbon and hydrological processes that are especially relevant during $\mathrm{F} / \mathrm{T}$ transitions. Accurate estimates of soil temperature and $\mathrm{F} / \mathrm{T}$ conditions are critical in this context. At northern latitudes, carbon source-sink activity is strongly correlated with the length of the vegetation growing season, which, for the most part, coincides with the summer period of thawed conditions. Moreover, soil respiration strongly depends on soil temperature conditions. Finally, hydrological conditions change dramatically between frozen and thawed soil conditions (Zhang et al. 2011; Kimball et al. 2004a).

In this study, the potential of the $\mathrm{F} / \mathrm{T}$ assimilation to improve estimates of land surface (skin) and soil temperature is investigated. To this end, an algorithm was developed for the assimilation of binary $\mathrm{F} / \mathrm{T}$ observations into the NASA Catchment land surface model (Koster et al. 2000 ) within the NASA Goddard Earth Observing System, version 5 (GEOS-5), modeling and assimilation framework. The assimilation algorithm includes a newly developed observation operator that diagnoses the $\mathrm{F} / \mathrm{T}$ state of the Catchment model and is compatible with the information contained in the remotely sensed landscape $\mathrm{F} / \mathrm{T}$ state at different microwave frequencies. The $\mathrm{F} / \mathrm{T}$ analysis consists of a rule-based approach that updates Catchment model prognostic variables for surface and soil temperature in response to binary $\mathrm{F} / \mathrm{T}$ observations and considers forecast and observation errors. To test the methodology, an observing system simulation experiment is conducted using synthetically generated F/T observations. The ultimate goal of this study is to provide a framework for the assimilation of F/T retrievals from SMAP into the Catchment model in the context of the SMAP level 4 surface and root-zone soil moisture (L4_SM) algorithm (Reichle 2012) and the SMAP level 4 carbon (L4_C) algorithm (Kimball et al. 2012). Future research will explore the direct assimilation of brightness temperature or backscatter measurements to analyze the landscape $\mathrm{F} / \mathrm{T}$ state.

\section{F/T detection using remote sensing}

At microwave frequencies, the landscape dielectric constant and thus the radar backscatter and the emission of passive microwaves undergo large temporal changes associated with corresponding changes in the predominant landscape F/T state within the satellite footprint (Mironov et al. 2010), which makes spaceborne 
microwave measurements well suited for global $\mathrm{F} / \mathrm{T}$ monitoring (Kim et al. 2011). In most studies, $0^{\circ} \mathrm{C}$ is considered the temperature threshold between the frozen and thawed states (Colliander et al. 2012). The temperature at which the F/T transition occurs, however, varies with the water solute concentration and shows strong heterogeneity across different landscape elements and within the satellite field of view. Thus, the $0^{\circ} \mathrm{C}$ threshold is only an approximation of the landscape $\mathrm{F} / \mathrm{T}$ transition point.

The contribution of different land surface elements to the retrieved $\mathrm{F} / \mathrm{T}$ index depends on the microwave frequency used for the $\mathrm{F} / \mathrm{T}$ classification. Colliander et al. (2012) used QuikSCAT Ku-band (13.4 GHz) backscatter measurements to investigate the relationship between individual land surface elements (e.g., soil, snow cover, and vegetation) and the aggregate landscape $F / T$ state indicated by the surface backscatter. It was observed that the temperature of the soil and that of vegetation stems and branches are generally better indicators of $\mathrm{Ku}$-band $\mathrm{F} / \mathrm{T}$ dynamics than surface air temperature, with soil temperature being a better indicator than vegetation temperature. Colliander et al. (2012) did not consider the effect of snow cover despite the fact that for their study domain the frozen condition is dominated by a snow-covered landscape. The rationale for their approach is the fact that the landscape thawing can be detected even under snow-covered conditions, as demonstrated by Kimball et al. $(2004 a, b)$ using Ku-band measurements from the NASA Scatterometer. The freeze-thaw product for SMAP will be derived using a time series analysis of the high-resolution L-band $(1.4 \mathrm{GHz})$ radar backscatter (Entekhabi et al. 2010). Because of their longer wavelength, L-band observations from SMAP should be less sensitive to snow and vegetation scattering effects under dry/frozen snow conditions and penetrate more deeply into the soil than $\mathrm{Ku}-$ band measurements. This increases the sensitivity of the microwave signals to the $\mathrm{F} / \mathrm{T}$ state of the underlying surface soil layer. However, for wet snow the penetration depth of microwaves is drastically reduced to a few centimeters or less (Mätzler and Schanda 1984). Thus, sensitivity to soil conditions is minimal under wet snow, regardless of the microwave frequency, and the satellite signal will largely reflect snow cover conditions when a significant amount of wet snow is present on the surface.

\section{F/T diagnosis using the Catchment land surface model}

This section first provides a brief description of the NASA GEOS-5 Catchment model (Koster et al. 2000; Ducharne et al. 2000; Reichle et al. 2011; Reichle 2012), a state-of-the-art global land surface model. Next, an observation operator is introduced for the diagnosis of the landscape $\mathrm{F} / \mathrm{T}$ state in the model. This observation operator is needed for the $\mathrm{F} / \mathrm{T}$ analysis (section 4 ) and is designed to be compatible with the information contained in remotely sensed $\mathrm{F} / \mathrm{T}$ observations at different microwave frequencies.

\section{a. Catchment model overview}

The Catchment model's basic computational unit is the hydrological catchment (or watershed). In each catchment, the vertical profile of soil moisture is determined by the equilibrium soil moisture profile from the surface to the water table and by two additional variables that describe deviations from the equilibrium profile in a $1-\mathrm{m}$ root-zone layer and in a $2-\mathrm{cm}$ surface layer, respectively. Based on soil moisture, each catchment is separated into three distinct and dynamically varying subareas: a saturated region, an unsaturated region, and a wilting region. The Catchment model also includes a three-layer snow model that accounts for snow melting and refreezing, dynamic changes in snow density, snow insulating properties, and other physics relevant to the growth and ablation of the snowpack (Lynch-Stieglitz 1994).

In the snow-free portion of the catchment, the surface energy balance is computed separately for the saturated, unsaturated, and wilting subareas of each catchment. In each of these three subareas, the land surface temperature is modeled with surface temperature prognostic variables that are specific to the soil moisture regime $\left(T_{C_{1}}\right.$ for the saturated region, $T_{C_{2}}$ for the unsaturated region, and $T_{C_{4}}$ for the wilting region). The effective soil depth associated with the $T_{C_{1}}, T_{C_{2}}$, and $T_{C_{4}}$ variables is negligible except for areas with broadleaf evergreen (typically tropical) land cover (Reichle 2012), which are of little importance for $\mathrm{F} / \mathrm{T}$ studies. The area-weighted average of the three prognostic surface temperature variables determines the surface temperature in the absence of snow $T_{\text {surf }}^{\text {no snow }}$, which is then averaged (again area weighted) with the surface snow temperature $T_{\text {surf }}^{\text {snow }}$, to provide the land surface temperature $T_{\text {surf }}$ of the entire catchment:

$$
T_{\text {surf }}=(1-\text { asnow }) T_{\text {surf }}^{\text {no snow }}+(\text { asnow }) T_{\text {surf }}^{\text {snow }} .
$$

The surface snow temperature and the snow area fraction asnow are themselves diagnosed from the model's snow prognostic variables (snow water equivalent SWE, snow depth, and snow heat content).

Subsurface temperatures are modeled using a soil heat diffusion model that consists of six layers. The thicknesses of the layers are about $10,20,40,75,150$, and $1000 \mathrm{~cm}$ starting from the topmost soil temperature layer. The layer thicknesses are the same for all catchments and each layer's soil temperature represents an average value over the entire catchment. The prognostic 
variables for the heat diffusion model are the ground heat contents ght in the six layers from which the soil temperatures $T_{\text {soil }}$ in each layer are diagnosed. For the remainder of this paper, ght and $T_{\text {soil }}$ refer to the values in the topmost $(10 \mathrm{~cm}$ thick) soil layer only.

\section{b. Freeze-thaw state in the Catchment model}

The $\mathrm{F} / \mathrm{T}$ analysis (section 4) requires diagnosing the landscape $\mathrm{F} / \mathrm{T}$ state of the Catchment model based on its prognostic variables. As outlined in section 2, the landscape $\mathrm{F} / \mathrm{T}$ state observed by L-band microwave remote sensing is assumed to be primarily related to the nearsurface soil and vegetation canopy temperature under dry/ frozen snow condition. Under wet snow, however, the satellite $\mathrm{F} / \mathrm{T}$ signal will largely reflect snow cover conditions. We therefore first define an effective temperature $T_{\text {eff }}$ that vertically averages the (snow free) portion of the surface temperature and the top-layer soil temperature:

$$
T_{\text {eff }}=(1-\alpha) T_{\text {soil }}+\alpha T_{\text {surf }}^{\text {no snow }} .
$$

Given the wavelengths used for F/T remote sensing, which typically range from 1 to $20 \mathrm{~cm}$, and the resulting penetration depths, the contribution of the lower-layer soil temperatures to the microwave signal is small and neglected here. The parameter $\alpha$ determines the relative contributions of the surface temperature and the soil temperature and can be adjusted according to the microwave frequency used for the $\mathrm{F} / \mathrm{T}$ classification so that it better reflects sensor signal penetration depth. Besides the effective temperature, additional information on the landscape $\mathrm{F} / \mathrm{T}$ state is contained in the modeled snow conditions. Here, asnow is most relevant. In the Catchment model, the snow cover fraction increases linearly with the SWE during the accumulation phase and reaches full cover (asnow $=100 \%$ ) when the total amount of SWE accumulated over the catchment reaches a model constant of SWEMIN $=26 \mathrm{~kg} \mathrm{~m}^{-2}$ (Reichle et al. 2011).

The landscape $\mathrm{F} / \mathrm{T}$ state is then diagnosed from the Catchment model variables via the following observation operator, which is also illustrated in Fig. 1:

$$
\begin{aligned}
& \text { Thawed( } \mathrm{F} / \mathrm{T}=1) \quad \text { if } \\
& T_{\text {eff }} \geq T_{\text {eff_Threshold }} \text { and asnow }<\text { asnow }_{\text {Threshold }} \\
& \text { Frozen }(\mathrm{F} / \mathrm{T}=-1) \text { if } \\
& T_{\text {eff }}<T_{\text {eff_Threshold }} \text { or asnow } \geq \text { asnow }_{\text {Threshold. }}
\end{aligned}
$$

The effective temperature that determines the transition between frozen and thawed conditions is $T_{\text {eff_Threshold }}=0^{\circ} \mathrm{C}$.

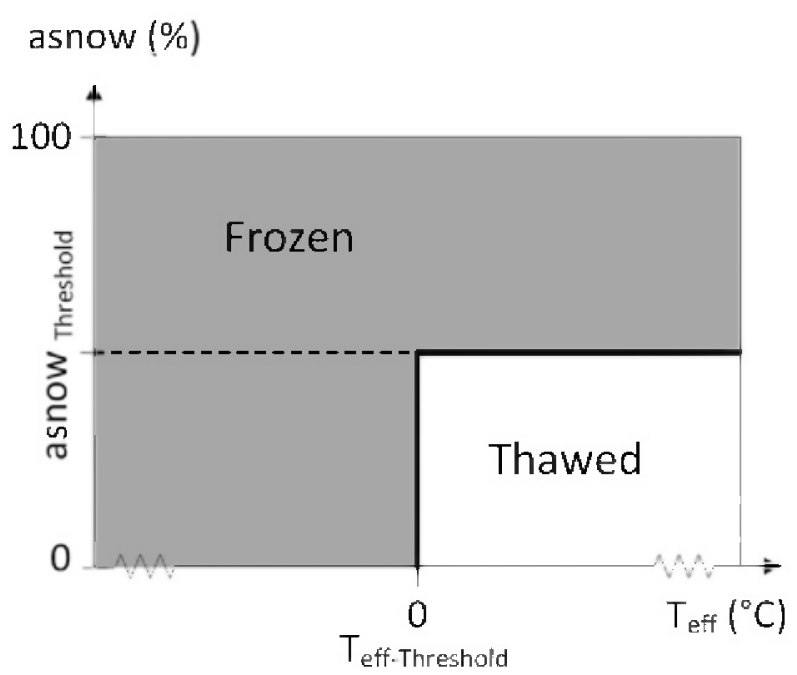

FIG. 1. Schematic representation of the model diagnosis of the land surface F/T state as a function of effective temperature and the snow cover fraction.

The snow cover threshold value asnow Threshold determines the maximum modeled snow cover fraction that is still compatible with a thawed condition. The penetration depth at $\mathrm{C}$ band $(5.6 \mathrm{GHz})$ can be as large as several meters in dry snow conditions (Bingham and Drinkwater 2000; Dall et al. 2001) and is likely even larger at L band $(1.27 \mathrm{GHz}$; Rignot et al. 2001). For wet snow, however, the penetration depth of microwaves is drastically reduced to a few centimeters or less (Mätzler and Schanda 1984). The value for asnow Threshold is fixed at $10 \%$ in this study and depends on the microwave frequency and the associated penetration depth through snow.

\section{4. $F / T$ data assimilation module ( $F / T$ analysis)}

The assimilation of $\mathrm{F} / \mathrm{T}$ observations is conceptually similar to the assimilation of snow cover observations. In both cases, the observed variable is, at least at the satellite footprint scale, essentially a binary observation. [Note that the daily SMAP F/T product provides categorical information including frozen, thawed, transitional, and inverse transitional $\mathrm{F} / \mathrm{T}$ states, with the latter two occurring when the $\mathrm{F} / \mathrm{T}$ observations for the morning and evening overpasses indicate opposing conditions (McDonald et al. 2012)]. Binary observations cannot be assimilated with a Kalman filter, because this requires continuous variables. For the assimilation of $\mathrm{F} / \mathrm{T}$ observations, we propose a rulebased assimilation approach, similar to the rule-based assimilation of binary snow cover observations (Rodell and Houser 2004). In short, if the model forecast and 


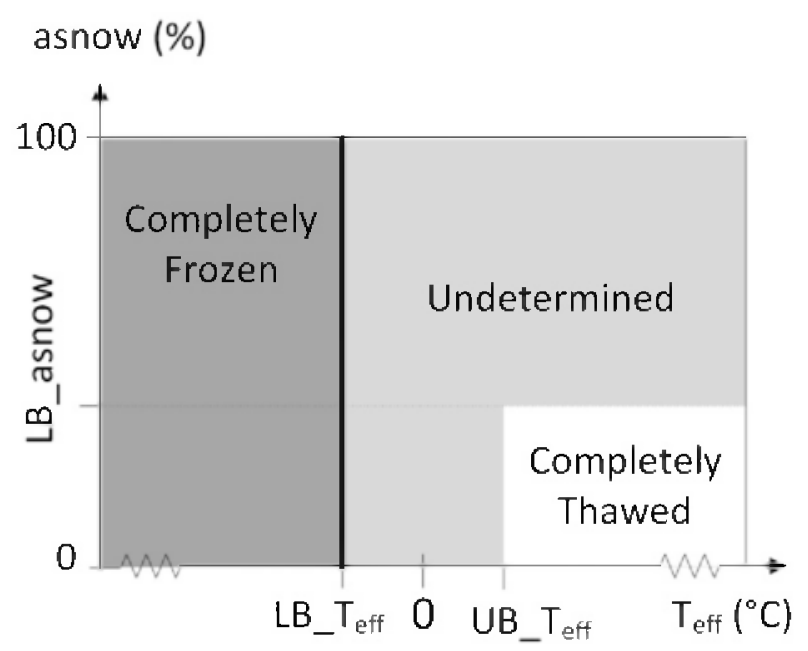

FIG. 2. Schematic representation of three distinct F/T state regimes defined by upper and lower uncertainty bounds on the effective temperature and snow cover thresholds for the purpose of the $\mathrm{F} / \mathrm{T}$ analysis. The upper bound for the snow cover threshold is set to $\mathrm{UB}_{\text {annow }}=100 \%$.

the corresponding SMAP observations disagree on the $\mathrm{F} / \mathrm{T}$ state, that is, if the model indicates frozen conditions and observation indicates thawed conditions (or vice versa), the model prognostic variables related to the soil temperature and the snow-free surface temperature are adjusted to match the observed $\mathrm{F} / \mathrm{T}$ condition more closely. To account for model and observation errors, the delineation between frozen and thawed regimes is defined with some uncertainty in the assimilation algorithm, as will be detailed below (section 4a).

\section{a. Uncertainty in $F / T$ simulations and observations}

The perhaps simplest $\mathrm{F} / \mathrm{T}$ analysis could use the observation operator defined in Eq. (3) to determine the $\mathrm{F} / \mathrm{T}$ state of the model forecast and then apply increments to switch the model's F/T state whenever the model's F/T state differs from that of the observations. However, such an analysis would ignore any uncertainty (representativeness error) associated with the formulation of the observation operator [Eq. (3)]. It would also ignore any errors in the observations themselves.

For the purpose of the F/T analysis, we therefore refine the observation operator by introducing a regime of undetermined F/T status, which is defined by upper and lower bounds for the effective temperature and snow cover thresholds, as illustrated in Fig. 2. Specifically, the model F/T state for the purpose of the F/T analysis is

$$
\begin{aligned}
& \text { Completely Thawed( } \mathrm{F} / \mathrm{T}=1) \text { if } \\
& T_{\text {eff }}>\mathrm{UB}_{T_{\text {eff }}} \text { and asnow }<\mathrm{LB}_{\text {asnow }} \\
& \text { Completely Frozen( } \mathrm{F} / \mathrm{T}=-1) \text { if } \\
& T_{\text {eff }}<\mathrm{LB}_{T_{\text {eff }}} \text { or asnow }>\mathrm{UB}_{\text {asnow }} \\
& \text { Undetermined(F/T }=0) \text { otherwise. }
\end{aligned}
$$

In this study, $\mathrm{UB}_{T_{\text {eff }}}$ and $\mathrm{LB}_{T_{\text {eff }}}$ are fixed at $1{ }^{\circ} \mathrm{C}$ and $-1^{\circ} \mathrm{C}$, and $\mathrm{LB}_{\text {asnow }}$ is set to $5 \%$. A value of $100 \%$ was chosen for $\mathrm{UB}_{\text {asnow. }}$. This assigns an "undetermined" $\mathrm{F} / \mathrm{T}$ regime to situations with considerable snow cover on soil that is thawed or close to thawing. Under these circumstances, it is difficult to determine whether the model $\mathrm{F} / \mathrm{T}$ state should be thawed or frozen in a manner that would be fully consistent with the retrieval algorithm that was used to determine the value of the $\mathrm{F} / \mathrm{T}$ observation.

The "undetermined" regime impacts the computation of the increments in two ways. First, if the model forecast F/T state is "undetermined," no increments will be applied. With increasingly uncertain forecast or retrieval $\mathrm{F} / \mathrm{T}$ estimates, the undetermined regime should expand and fewer observations will impact the data assimilation results. Second, the upper and lower bounds for the effective temperature threshold $\left(\mathrm{UB}_{T_{\text {eff }}} ; \mathrm{LB}_{T_{\text {eff }}}\right)$ will be used to formulate the rulebased increments that result from the $F / T$ analysis (section 4b). In either case, the "undetermined" regime implicitly assigns weight to the model forecast in the analysis update and thus assumes imperfect observations.

\section{b. Update rules}

The assimilation of $\mathrm{F} / \mathrm{T}$ observations is based on a number of rules. No updates are performed (i) if both the model and the observations agree on the $\mathrm{F} / \mathrm{T}$ state or (ii) if the model $\mathrm{F} / \mathrm{T}$ state is undetermined per Eq. (4). When the observations and simulations indicate a contrasting $\mathrm{F} / \mathrm{T}$ state, then the model prognostic variables associated with $T_{\text {eff }}$ are updated (i.e., $T_{C_{1}}, T_{C_{2}}, T_{C_{4}}$, and ght; section 3 ). Specifically, if the observations indicate a thawed condition $(\mathrm{F} / \mathrm{T}=1)$ whereas the model is in a frozen regime, then $T_{\text {eff }}$ is increased to $\mathrm{LB}_{T_{\text {eff }}}$. Conversely, if the observations indicate freezing $(\mathrm{F} / \mathrm{T}=-1)$ and the model is in a thawed regime, then $T_{\text {eff }}$ is decreased to $\mathrm{UB}_{T_{\text {eff }}}$. The updates can be summarized as follows:

$$
T_{\text {eff }}^{+}=T_{\text {eff }}^{-}+\Delta T,
$$


where

$$
\begin{aligned}
& \Delta T=\min \left(\mathrm{UB}_{T_{\text {eff }}}-T_{\text {eff }}^{-}, 0\right) \leq 0 \quad \text { if } \\
& \operatorname{obs}(\mathrm{F} / \mathrm{T})=-1, \operatorname{model}(\mathrm{F} / \mathrm{T})=+1, \\
& \Delta T=\max \left(\mathrm{LB}_{T_{\text {eff }}}-T_{\mathrm{eff}}^{-}, 0\right) \geq 0 \quad \text { if } \\
& \operatorname{obs}(\mathrm{F} / \mathrm{T})=+1, \operatorname{model}(\mathrm{F} / \mathrm{T})=-1, \quad \text { and } \\
& \Delta T=0 \quad \text { otherwise. }
\end{aligned}
$$

In this equation, $T_{\text {eff }}^{-}$represents the priori estimate and $T_{\text {eff }}^{+}$represents the analysis. The same increment $\Delta T$ is applied to the prognostic temperature variables $T_{C_{1}}, T_{C_{2}}$, and $T_{C_{4}}$ (the weighted average of which determines $T_{\text {surf }}^{\text {no snow }}$ ) and the soil temperature $T_{\text {soil }}$. For the latter, the ght (the model prognostic variable that determines the soil temperature) is adjusted accordingly to match the updated soil temperature $T_{\text {soil }}^{+}$. Note that the updates to $T_{C_{1}}, T_{C_{2}}$, and $T_{C_{4}}$ also adjust $T_{\text {surf }}$ following Eq. (1). In this study, we are only updating the surface temperature and the soil temperature (and ground heat content) of the topmost soil layer. For future studies, updating the temperature of lower soil layers can also be considered.

The update rules [Eq. (5)] intentionally do not adjust the snow variables directly. As mentioned in section $4 \mathrm{a}, \mathrm{UB}_{\text {asnow }}=100 \%$ has been selected to avoid uncertainties related to the role of snow in determining the F/T state. This choice is supported by several experiments that were performed with smaller threshold values for $\mathrm{UB}_{\text {asnow }}$ and in which a portion of the snow was removed if the observed $\mathrm{F} / \mathrm{T}$ state indicated thawed conditions. These additional experiments (not shown) indicated that (error prone) $\mathrm{F} / \mathrm{T}$ observations sometimes mistakenly removed the model snow, which resulted in large subsequent forecast errors. It is difficult to recover from such errors, because once the model snow has been removed, the missing snow cannot easily be redeposited at future analysis times because of the lack of quantitative information about snow mass in the $\mathrm{F} / \mathrm{T}$ observations. Consequently, in the following, the snow prognostic variables are not adjusted as part of the F/T analysis update. Nevertheless, at later time steps the model's snow conditions will respond to the adjusted soil temperatures and corresponding updated hydrological fluxes.

\section{Synthetic twin experiment}

The twin experiment consists of several components. A Catchment land surface model integration serves as the "truth" and is used (i) to generate synthetic F/T observations and (ii) to validate the analysis results. The data assimilation experiment is performed with imperfect simulations and observations. The synthetic observed $\mathrm{F} / \mathrm{T}$ state is obtained by adding classification

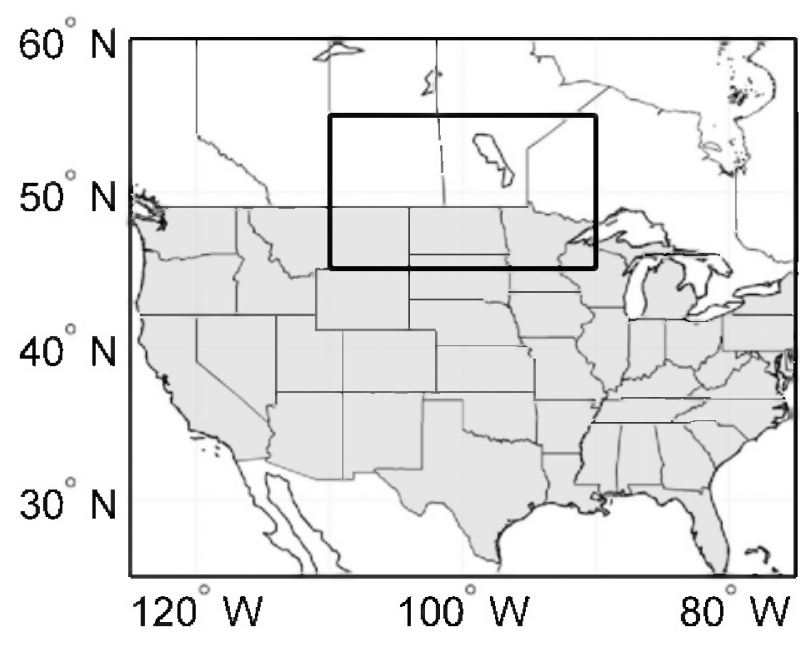

FIG. 3. Map of study domain.

error $\mathrm{CE}$ to the true $\mathrm{F} / \mathrm{T}$ state (section $5 \mathrm{~b}$ ). The imperfect Catchment land surface model integration is produced with a different forcing dataset to mimic forcing errors. This imperfect model simulation without data assimilation is referred to as the open loop (OL; see discussion in section $5 \mathrm{~b}$ ). The $\mathrm{F} / \mathrm{T}$ analysis is performed by assimilating the synthetic $\mathrm{F} / \mathrm{T}$ observations into the imperfect model simulation using erroneous forcing data and is referred to as the data assimilation (DA) integration. The OL and DA results are compared against the truth and the relative importance of assimilating observed $\mathrm{F} / \mathrm{T}$ data is investigated (section 6).

\section{a. Study domain and time period}

The study domain is a region in North America between $45^{\circ}$ and $55^{\circ} \mathrm{N}$ and $90^{\circ}$ and $110^{\circ} \mathrm{W}$ (Fig. 3). The simulations are performed on a $36-\mathrm{km}$ Equal-Area Scalable Earth Grid (EASE-Grid), covering 1137 grid cells in the study domain. The Catchment model integration is conducted using the GEOS-5 land data assimilation system (Reichle et al. 2014) with a time step of $20 \mathrm{~min}$. The selected period of investigation is 8 years (from 1 January 2002 to 1 January 2010), and the temporal resolution of the model output is 3 hourly. The model was spun up by cycling 10 times through the 1 -yr period from 1 January 2001 to 1 January 2002 .

\section{b. Synthetic truth, synthetic observations, and open loop}

The synthetic truth is based on a Catchment model simulation that uses surface meteorological forcing data from the Modern-Era Retrospective Analysis for Research and Applications (MERRA; Rienecker et al. 2011). The MERRA data product is provided at an hourly temporal resolution and a $1 / 2^{\circ} \times 2 / 3^{\circ}$ (latitude-longitude) 


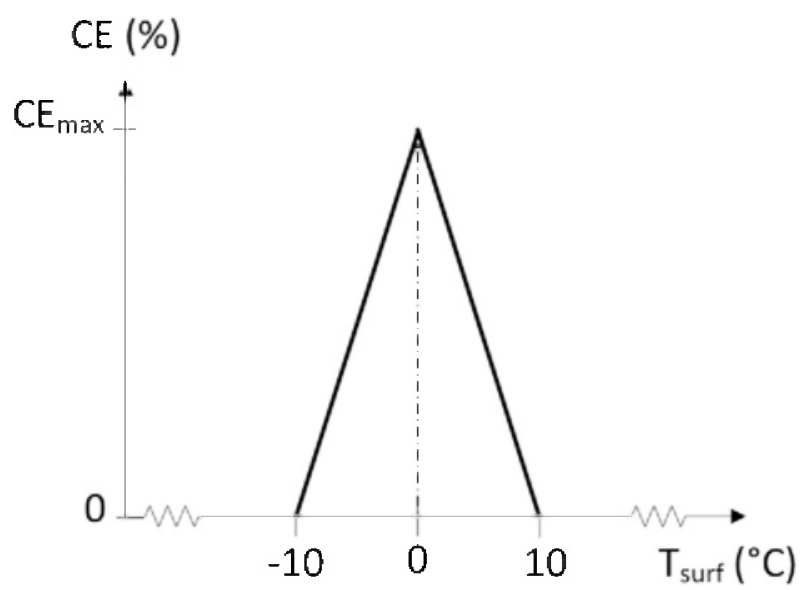

FIG. 4. Classification error function

spatial resolution. The resulting 8 years of synthetic true hydrological state variables and fluxes are used for the validation of the $\mathrm{F} / \mathrm{T}$ analysis (DA). The synthetic true $\mathrm{F} / \mathrm{T}$ state is obtained by applying the observation operator [Eq. (3)] using $\alpha=0.5$, asnow Threshold $=10 \%$, and $T_{\text {eff } \text { Threshold }}=0^{\circ} \mathrm{C}$

The synthetic observed F/T indices are obtained by corrupting the true $\mathrm{F} / \mathrm{T}$ dataset with spatially uncorrelated synthetic classification error. Specifically, the classification error is defined by the probability of misclassification. The SMAP mission requirements call for an $\mathrm{F} / \mathrm{T}$ product with no more than $20 \%$ mean spatial classification error (McDonald et al. 2012). Here, we assume that the classification error is greatest near $0^{\circ} \mathrm{C}$, where it reaches $\mathrm{CE}_{\max }$, linearly tapers off toward colder and warmer temperatures, and vanishes below $-10^{\circ}$ and above $+10^{\circ} \mathrm{C}$. That is, this physically based classification error model is given by the following piecewise linear function of the land surface temperature:

$\mathrm{CE}= \begin{cases}\mathrm{CE}_{\max } \frac{T_{\text {surf }}+10}{10} & -10^{\circ} \leq T_{\text {surf }} \leq 0^{\circ} \mathrm{C} \\ \mathrm{CE}_{\max } \frac{10-T_{\text {surf }}}{10} & 0^{\circ} \leq T_{\text {surf }} \leq 10^{\circ} \mathrm{C} \\ 0 & T_{\text {surf }}>10^{\circ} \text { or } T_{\text {surf }}<-10^{\circ} \mathrm{C} .\end{cases}$

This parameterization of the classification error is illustrated in Fig. 4.

The synthetic $\mathrm{F} / \mathrm{T}$ observations are generated at each time and for each location (or grid cell) by obtaining the probability of misclassification based on the land surface temperature from Eq. (6). We then randomly select a number from a uniform distribution between 0 and 1 . If the selected random number is less than the specified classification error for that land surface temperature, then the observed $\mathrm{F} / \mathrm{T}$ index is obtained by changing the sign of true $\mathrm{F} / \mathrm{T}$ classification. Otherwise, the observed $\mathrm{F} / \mathrm{T}$ index is equal to the true $\mathrm{F} / \mathrm{T}$ state. The sensitivity of the data assimilation experiments to different levels of observation classification errors will be investigated below.

The open-loop dataset is obtained from an integration of the Catchment model with forcing data that differ from those used for the truth. Forcing errors were imposed by replacing the MERRA surface meteorological forcing fields with data from the Global Land Data Assimilation System (GLDAS; Rodell et al. 2004) as used in a former version of the NASA GMAO seasonal prediction system at 3-hourly temporal resolution and at $2.0^{\circ} \times 2.5^{\circ}$ (latitude-longitude) spatial resolution. The hydrological response associated with the differences between MERRA and GLDAS in precipitation and radiation timing and intensity results in considerable differences in the diagnosed $\mathrm{F} / \mathrm{T}$ state at the grid scale.

\section{c. F/T assimilation setup}

The $\mathrm{F} / \mathrm{T}$ assimilation experiment uses the same model settings as described for the open-loop model, that is, it uses GLDAS forcings to mimic forcing errors relative to the MERRA truth. No additional perturbations are imposed and a single deterministic integration is performed for a period of 8 years (from 1 January 2002 to 1 January 2010). In this study, the synthetic observed F/T index is assimilated into the imperfect model integration at 0600 and 1800 local time (LT; F/T analysis update). The proposed assimilation time steps are compatible with the planned overpass times of SMAP.

The various tunable parameters in the diagnosis of the (uncertain) F/T state and the update rules are as follows. The parameter $\alpha$ [which determines the weight of the components of the effective temperature; Eq. (2)] is set to 0.5 for the generation of $\mathrm{F} / \mathrm{T}$ observations. This parameter is tunable and the sensitivity of data assimilation experiments to this parameter in the observation operator [Eq. (3)] will be explored in section 6b. The values for the lower and upper bounds on the snow cover threshold ( $\left.\mathrm{LB}_{\text {asnow }} ; \mathrm{UB}_{\text {asnow }}\right)$ are $5 \%$ and $100 \%$, respectively. The uncertainty range for asnow accounts for the combined uncertainty associated with the diagnosis of the modeled $\mathrm{F} / \mathrm{T}$ state and the classification of the $\mathrm{F} / \mathrm{T}$ observations in the presence of snow. To account for the uncertainty of the $0^{\circ} \mathrm{C}$ threshold value across different landscape elements within the satellite field of view, the upper and lower bounds for the effective temperature thresholds are $+1^{\circ}$ and $-1^{\circ} \mathrm{C}$, respectively. This range in the $T_{\text {eff }}$ Threshold also accounts for variability (or subgrid heterogeneity) in a number of factors, including soil exposure (vegetation cover), topography, mineral/organic 
TABLE 1. Metrics for $\mathrm{OL}$ vs truth estimates for a period of 8 years $(2002-10)$ and at 0600 and 1800 LT. The RMSE for $T_{\text {surf }}$ and $T_{\text {air }}$ is computed excluding times and locations where $T_{\text {air }}>$ $7^{\circ} \mathrm{C}$ or $T_{\text {air }}<-7^{\circ} \mathrm{C}$.

\begin{tabular}{clc}
\hline \hline Variables & \multicolumn{1}{c}{ Metric } & Value \\
\hline$T_{\text {surf }}$ & RMSE & $3.08^{\circ} \mathrm{C}$ \\
$T_{\text {soil }}$ & RMSE & $1.97^{\circ} \mathrm{C}$ \\
$\mathrm{F} / \mathrm{T}$ & Classification error & $4.85 \%$ \\
\hline
\end{tabular}

layer characteristics, and water solute concentration. The $\mathrm{F} / \mathrm{T}$ analysis may benefit from adjusting these uncertainty bounds in response to the $\mathrm{F} / \mathrm{T}$ classification error in the synthetic observations or in the model $\mathrm{F} / \mathrm{T}$ state, but in the present paper we keep the bounds fixed.

\section{d. Validation of temperature estimates}

By design, the analysis update [Eq. (5)] does not alter the F/T state of the model forecast, but the update rules will alter the temperature variables whenever the model forecast $\mathrm{F} / \mathrm{T}$ state differs from the observed $\mathrm{F} / \mathrm{T}$ index. It is expected that the differences in surface and soil temperatures (with respect to the truth) are smaller in the assimilation estimates than in the open-loop estimates. We therefore focus the validation on the computation of root-mean-square errors (RMSEs) of surface and soil temperatures versus the truth dataset.

The F/T data assimilation is expected to be most relevant when temperatures are near $0^{\circ} \mathrm{C}$ because it is straightforward to estimate the $\mathrm{F} / \mathrm{T}$ state accurately during clearly warm or cold conditions. We thus limit the validation to time steps where the air temperature is above $-7^{\circ}$ and below $+7^{\circ} \mathrm{C}$ (as indicated by the MERRA surface air temperatures). Furthermore, we restrict the validation to 0600 and 1800 LT only, compatible with the time of the SMAP overpasses.

\section{Results and discussion}

\section{a. $O L$ and $D A$ with standard settings}

To assess the impact of the imperfect forcing on the diagnosis of the $\mathrm{F} / \mathrm{T}$ state without data assimilation, we first examine the OL results. As mentioned in section 5, the OL utilizes GLDAS forcings and the "truth" utilizes MERRA forcings. When compared to the truth, the OL has an $\mathrm{F} / \mathrm{T}$ classification error of $4.85 \%$ (Table 1 ). The table also shows that the RMSE value for the OL surface temperature is $3.08^{\circ} \mathrm{C}$ and that of the first soil layer temperature is $1.97^{\circ} \mathrm{C}$.

Again, by design the $\mathrm{F} / \mathrm{T}$ analysis update does not alter the F/T state of the model forecast, and consequently the $\mathrm{F} / \mathrm{T}$ classification error of the assimilation estimates is nearly the same as that of the OL. But
TABLE 2. RMSE improvement ( $\triangle \mathrm{RMSE}=\mathrm{RMSE}_{\mathrm{OL}}$ $\mathrm{RMSE}_{\mathrm{DA}} ;{ }^{\circ} \mathrm{C}$ ) for $T_{\text {surf }}$ and $T_{\text {soil }}$, for different $\mathrm{CE}_{\mathrm{max}}$, excluding times and locations where $T_{\text {air }}>7^{\circ} \mathrm{C}$ or $T_{\text {air }}<-7^{\circ} \mathrm{C}$, for a period of 8 years $(2002-10)$ and at 0600 and 1800 LT.

\begin{tabular}{lcccc}
\hline \hline & \multicolumn{4}{c}{$\mathrm{CE}_{\max }$} \\
\cline { 2 - 5 }$\Delta \mathrm{RMSE}$ & $0 \%$ & $5 \%$ & $10 \%$ & $20 \%$ \\
\hline$T_{\text {surf }}\left({ }^{\circ} \mathrm{C}\right)$ & 0.206 & 0.192 & 0.178 & 0.149 \\
$T_{\text {soil }}\left({ }^{\circ} \mathrm{C}\right)$ & 0.061 & 0.049 & 0.036 & 0.006 \\
\hline
\end{tabular}

through the assimilation of the $\mathrm{F} / \mathrm{T}$ observations, we hope to reduce the OL temperature errors. The $\mathrm{F} / \mathrm{T}$ analysis involves adjusting the land surface effective temperature, and subsequently $T_{\text {surf }}^{\text {no snow }}$ and $T_{\text {soil }}$, if the observed and simulated $\mathrm{F} / \mathrm{T}$ states do not agree. Table 2 summarizes the reduction in RMSE ( $\triangle \mathrm{RMSE}=$ $\mathrm{RMSE}_{\mathrm{OL}}-\mathrm{RMSE}_{\mathrm{DA}}$ ) by assimilating synthetic $\mathrm{F} / \mathrm{T}$ observations with four different levels of classification error $\left(\mathrm{CE}_{\max }\right)$, and assuming default values for the tunable parameters, as introduced in section $5 \mathrm{c}$.

Assimilating observed $\mathrm{F} / \mathrm{T}$ indices without classification error results in an RMSE improvement of $0.206^{\circ} \mathrm{C}$ for the land surface temperature and an RMSE improvement of $0.061^{\circ} \mathrm{C}$ for the first layer soil temperature. When compared to the OL results for these two variables, the $\mathrm{F} / \mathrm{T}$ analysis results in relative RMSE improvements of $6.7 \%$ and $3.1 \%$ for $T_{\text {surf }}$ and $T_{\text {soil }}$, respectively. The skill improvement decreases monotonically with increasing classification error in the observations. For a $\mathrm{CE}_{\max }=20 \%$ the assimilation of $\mathrm{F} / \mathrm{T}$ observations still reduces the surface temperature RMSE by $0.149^{\circ} \mathrm{C}$, but it no longer improves the soil temperature estimates.

Figure 5 shows the $T_{\text {surf }}$ and $T_{\text {soil }}$ skill improvements in the study domain for the assimilation of $F / T$ observations with $\mathrm{CE}_{\max }=0 \%, 5 \%$, and $20 \%$. Figures $5 \mathrm{a}$ and $5 \mathrm{~b}$ show that as a result of assimilating perfect $\mathrm{F} / \mathrm{T}$ observations, the skill of $T_{\text {surf }}$ and $T_{\text {soil }}$ improves for almost all grid cells within the study domain. However, the efficiency of the $\mathrm{F} / \mathrm{T}$ analysis deteriorates as the classification error is increased (Figs. $5 c-d$ ). For $\mathrm{CE}_{\max }=20 \%$, many grid cells in the study domain have negative or no improvement in $T_{\text {soil }}$ skill. As mentioned above, the $\mathrm{F} / \mathrm{T}$ analysis may benefit from adjusting the uncertainty bounds in response to the classification error of the synthetic $\mathrm{F} / \mathrm{T}$ observations, but the above results indicate that using a single set of uncertainty bounds already provides reasonable assimilation estimates.

Figure 6 shows the skill improvement for each grid cell binned as a function of the number of analysis updates per grid cell (i.e., the skill improvement is spatially averaged across grid cells experiencing a similar number of analysis updates in time within the study domain). The 
a)

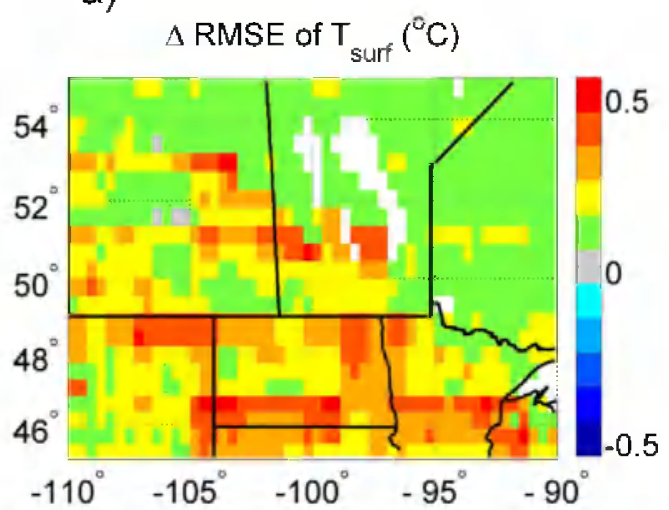

c)

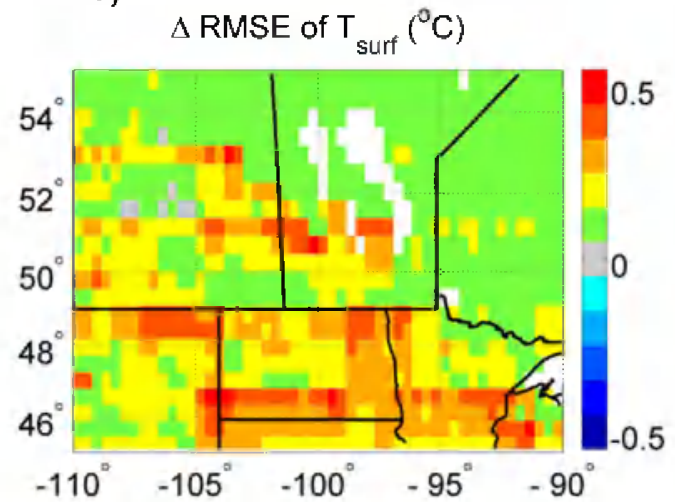

e)

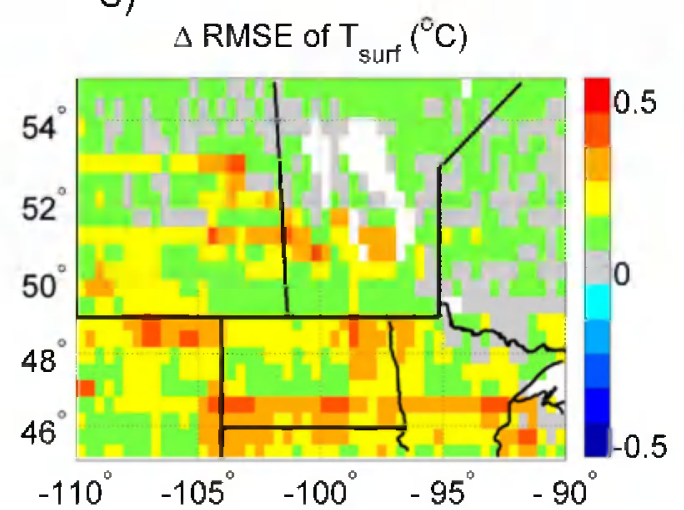

b) $\triangle$ RMSE of $\mathrm{T}_{\text {soil }}\left({ }^{\circ} \mathrm{C}\right)$

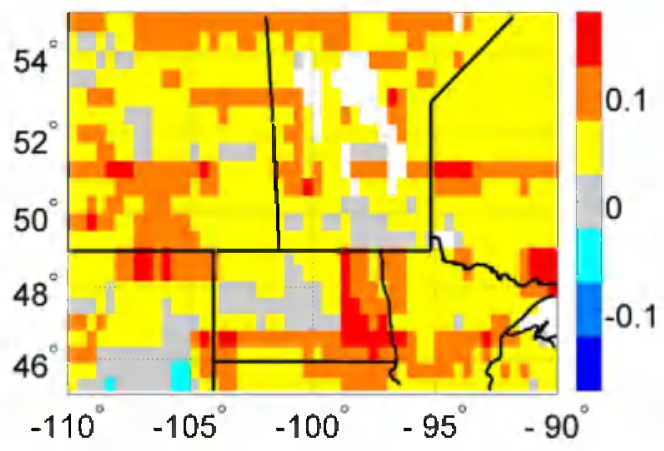

d)

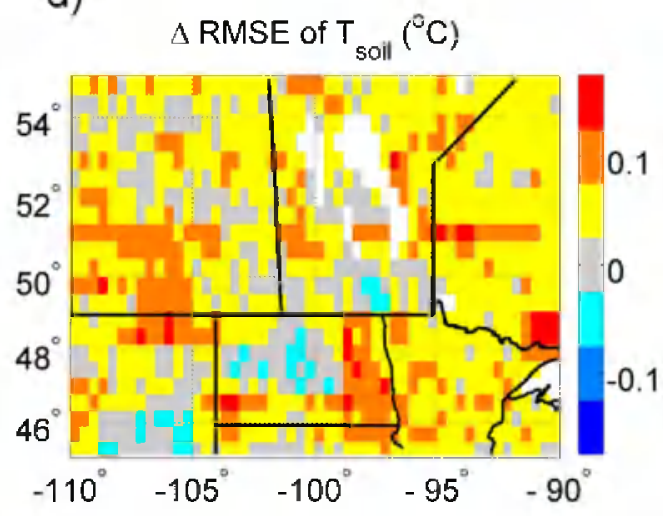

f)

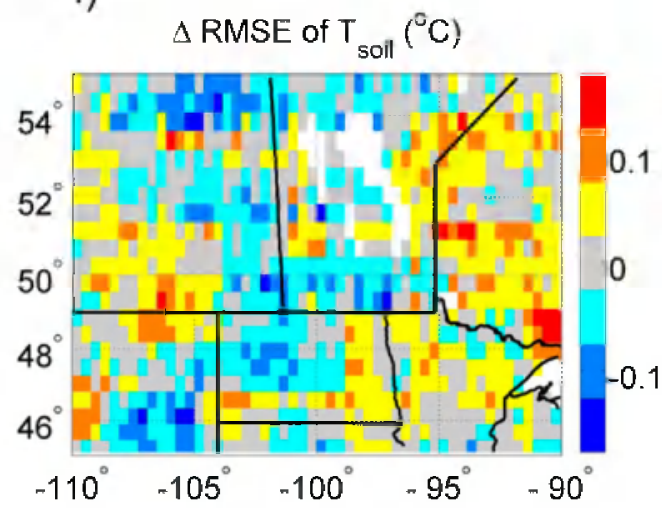

FIG. 5. The $\triangle$ RMSE (= RMSE $\mathrm{OL}_{\mathrm{OL}}-\mathrm{RMSE}_{\mathrm{DA}}$ ) in (left) $T_{\text {surf }}$ and (right) $T_{\text {soil }}$ across the study domain for assimilation of synthetic $\mathrm{F} / \mathrm{T}$ observations with $\mathrm{CE}_{\max }$ of (a),(b) $0 \%$; (c),(d) $5 \%$; and (e),(f) $20 \%$. A positive $\triangle$ RMSE indicates a skill improvement in the assimilation results. Lakes are shown in white. See Fig. 3 for a map of the study domain.

data points are assigned to six bins with equal numbers of grid cells. Each bin center is assigned the average number of analysis updates for the grid cells in that particular bin. When more error-free observations (Figs. 6a,b) or observations with modest classification errors (Figs. 6c,d) are assimilated, the average skill improves with the number of analysis updates for both the temperatures, $T_{\text {surf }}$ and $T_{\text {soil }}$. However, as the maximum classification error is increased to $20 \%$ (Figs. 6e,f), the average skill in the temperature variables does not improve with the number of analyses. This is due to the negative effect of assimilating misclassified observed $\mathrm{F} / \mathrm{T}$ indices into the model. 
a)

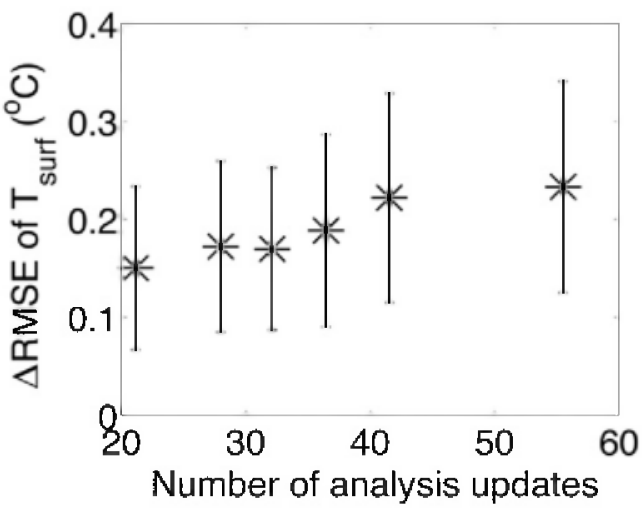

c)

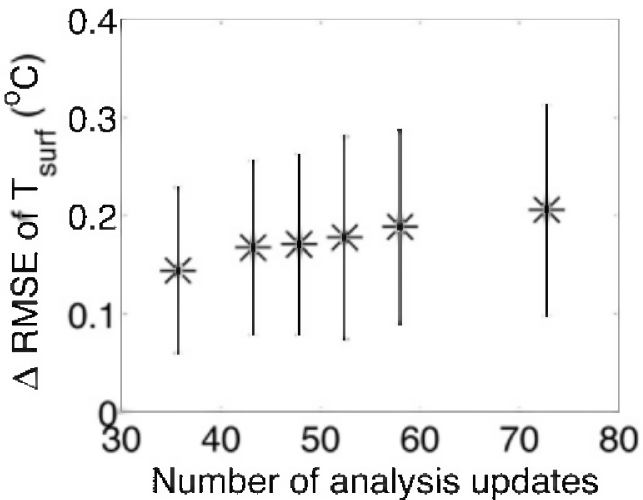

e)

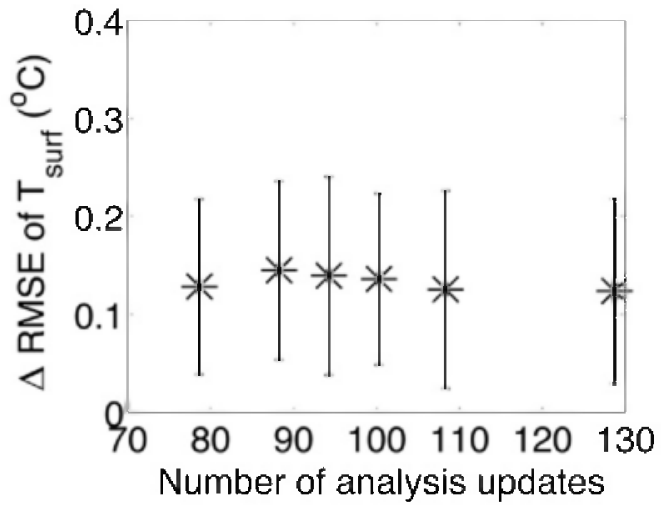

b)

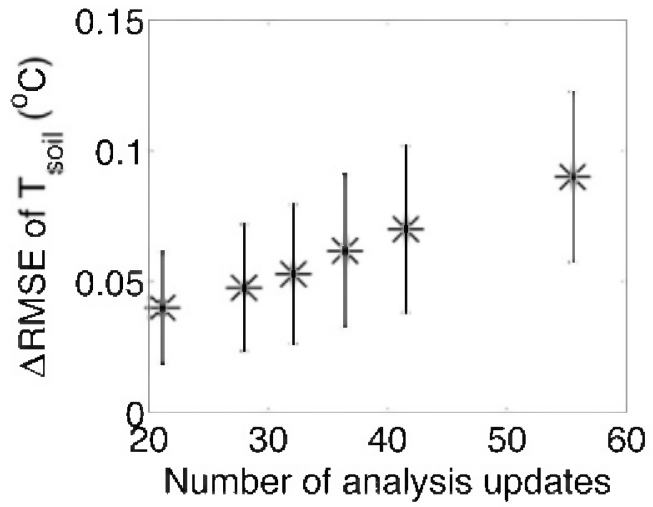

d)

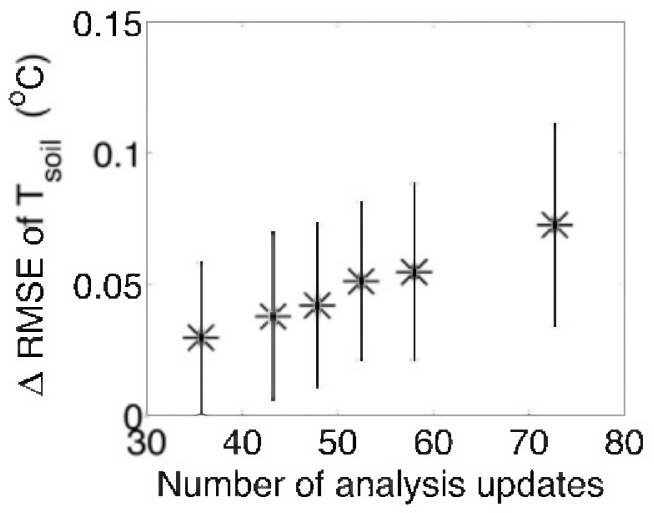

f)

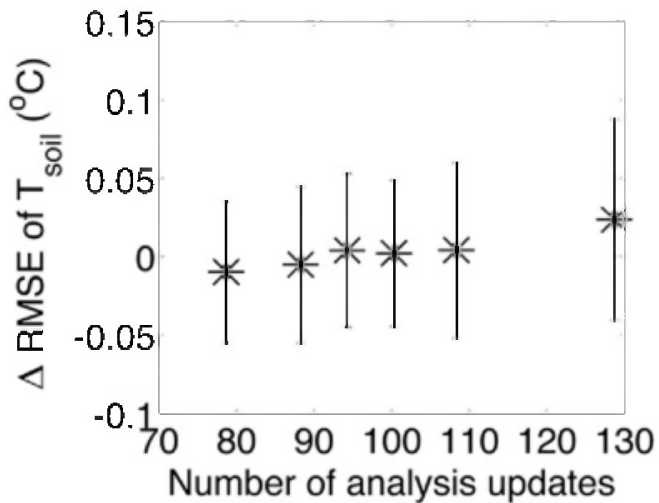

FIG. 6. Spatially averaged $\triangle$ RMSE for (left) $T_{\text {surf }}$ and (right) $T_{\text {soil }}$ with one spatial std dev around the mean as a function of the number of analysis updates for the assimilation of synthetic $\mathrm{F} / \mathrm{T}$ observations with $\mathrm{CE}_{\max }$ of (a),(b) $0 \%$; (c), (d) $5 \%$; and (e),(f) $20 \%$. A positive $\triangle$ RMSE indicates a skill improvement in the assimilation results.

b. Sensitivity of assimilation results to the formulation of the effective temperature

The effective temperature, which is an important variable in diagnosing the $\mathrm{F} / \mathrm{T}$ state, is a weighted average of the surface temperature in the absence of snow and the soil temperature [Eq. (2)]. The weight should be a function of the microwave penetration depth. An increase (decrease) in penetration depth results in a decrease (increase) in parameter $\alpha$ and hence an increase (decrease) in the weight of the soil temperature component of effective temperature. In this study, the 
a)

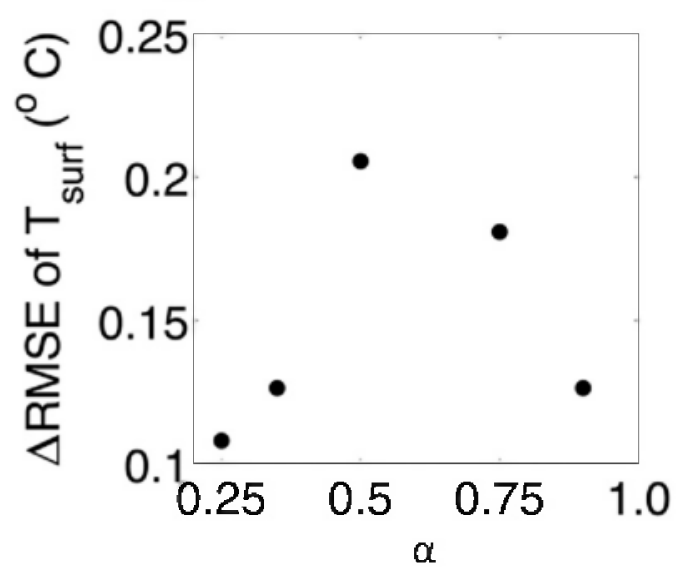

b)

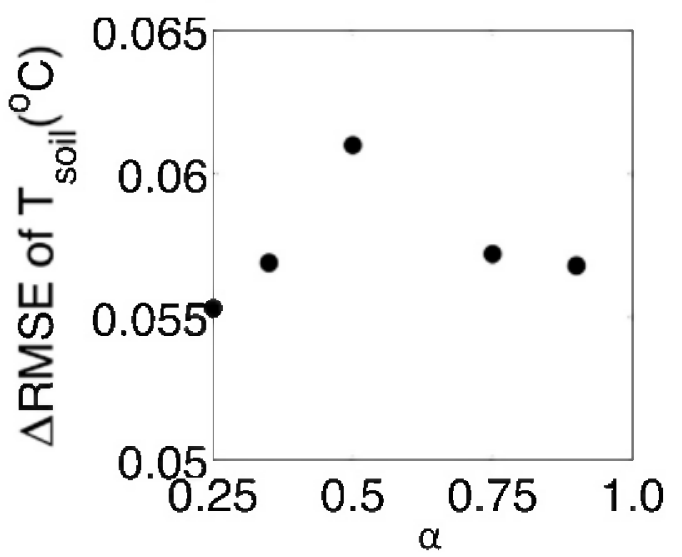

FIG. 7. The $\Delta$ RMSE for (a) $T_{\text {surf }}$ and (b) $T_{\text {soil }}$ as a function of the $\alpha$ parameter chosen in the observation operator. A positive $\triangle$ RMSE indicates a skill improvement in the assimilation results.

synthetic true $\mathrm{F} / \mathrm{T}$ state was obtained based on the assumption that the parameter $\alpha$ equals 0.5 . Thus, $T_{\text {surf }}^{\text {no snow }}$ and $T_{\text {soil }}$ have similar weights in determining the effective temperature and thus the $\mathrm{F} / \mathrm{T}$ state of the soil.

However, when determining the F/T index from (real) remote sensing observations, the relative effect of $T_{\text {surf }}^{\text {no snow }}$ and $T_{\text {soil }}$ in those observations is not known a priori. Here, we investigate the sensitivity of the DA performance to the choice of this factor in the observation operator. A physically meaningful range of $\alpha$ between 0.25 and 1 was selected. This means that the weight of soil temperature $T_{\text {soil }}$ ranges between 0.75 and 0 in the model.

The sensitivity of the assimilation results to the value of $\alpha$ in the forecast $\mathrm{F} / \mathrm{T}$ state is illustrated Fig. 7. The skill improvements ( $\triangle \mathrm{RMSE}$ ) are shown for the case where no classification error $\left(\mathrm{CE}_{\max }=0 \%\right)$ is associated with the assimilated $\mathrm{F} / \mathrm{T}$ indices. As expected, the maximum skill improvement for both $T_{\text {surf }}$ and $T_{\text {soil }}$ occurs when the parameter $\alpha$ is 0.5 , that is, when the $\alpha$ value that is used in the observation operator of the assimilation system matches the $\alpha$ value that was used to generate the synthetic $\mathrm{F} / \mathrm{T}$ observations. The figure shows that the sensitivity of $T_{\text {surf }}$ to the parameter $\alpha$ seems to be higher than that of $T_{\text {soil }}$. The skill of $T_{\text {surf }}$ is reduced by up to $50 \%$ when $\alpha$ is not selected correctly, while the skill is reduced by at most $8 \%$ for $T_{\text {soil. }}$ It is thus important to understand how different land surface variables contribute to the observed $\mathrm{F} / \mathrm{T}$ and to mimic this relationship adequately in the $\mathrm{F} / \mathrm{T}$ observation operator used in the data assimilation scheme.

\section{Conclusions}

In this study an algorithm for the diagnosis of the $F / T$ state in the NASA Catchment land surface model was developed. The algorithm is compatible with the information contained in remotely sensed retrievals of landscape $\mathrm{F} / \mathrm{T}$ state at different microwave frequencies. The GEOS-5 land data assimilation system in offline mode was updated with the newly designed $\mathrm{F} / \mathrm{T}$ assimilation module. The ultimate goal of this research is to provide a framework for the assimilation of SMAP F/T observations into the Catchment model.

The performance of the method for a synthetic experiment showed encouraging improvements in the skill of soil temperature and land surface temperature estimates. However, the average skill improvement depends on the classification error in the $\mathrm{F} / \mathrm{T}$ observations. In our synthetic study, the open-loop simulation has a modeled $\mathrm{F} / \mathrm{T}$ classification error of $4.85 \%$ error compared to the truth. When assimilating perfect (error free) F/T observations, the RMSE for land surface temperature $\left(T_{\text {surf }}\right)$ and soil temperature $\left(T_{\text {soil }}\right)$ improves by $6.7 \%$ and $3.1 \%$, respectively. Yet, the skill improvement decreases monotonically with increasing classification error in the assimilated $\mathrm{F} / \mathrm{T}$ observations. No more improvements in soil temperature were found with maximum classification errors of $\mathrm{CE}_{\max }=20 \%$ and fixed uncertainty bounds on the snow cover threshold and effective temperature. The assimilation estimates can perhaps be improved further by adjusting the uncertainty bounds in the rule-based update. For example, increased uncertainty bounds will prevent adverse effects from assimilating retrievals with increased classification errors. However, refinements of the algorithm calibration are left for future work.

The results also discuss the sensitivity of the data assimilation (DA) to the $\alpha$ parameter in the observation operator. This parameter controls the relative contribution 
of the snow-free surface temperature and the top-layer soil temperature to the $\mathrm{F} / \mathrm{T}$ state in the modeling system and impacts the temperature increments applied during the $\mathrm{F} / \mathrm{T}$ analysis. The maximum skill improvement can only be expected if the observation operator in the modeling system closely mimics the relative importance of various landscape components, including the surface and soil temperatures, in the determination of the satellite F/T observations. Therefore, the observation operator could also benefit from further tuning to improve the linkage between the modeled snow cover and the expected $\mathrm{F} / \mathrm{T}$ index retrieved from the microwave signal. Moreover, the limitations of the present study could perhaps be overcome in the future by directly assimilating backscatter or brightness temperature observations (instead of $\mathrm{F} / \mathrm{T}$ retrievals).

The regional domain of the experiment investigated in this research represents a relatively flat terrain area of central North America. In this region, the model without assimilation (open loop) produced an F/T classification error of only $4.85 \%$. This modeling error is a direct result of the assumption that all $\mathrm{F} / \mathrm{T}$ classification errors are solely due to errors in the forcing data (as reflected in the difference between the GLDAS and MERRA data). When the F/T assimilation method is applied with high-resolution satellite observations (instead of synthetic retrievals), we expect relatively larger errors in the simulated $\mathrm{F} / \mathrm{T}$ state, especially over regions with more complex topography (e.g., regions in western North America) where global forcing fields do not resolve the considerable heterogeneity of the surface conditions. The benefit of assimilating high-resolution $(3 \mathrm{~km})$ SMAP F/T retrievals is therefore expected to be greater for specific applications such as improving the simulation of ecohydrological processes. Additional benefits might be derived from combining the $\mathrm{F} / \mathrm{T}$ analysis presented here with established data assimilation algorithms that use satellite observations of land surface temperature, snow cover, or snow water equivalent (e.g., Reichle et al. 2010; De Lannoy et al. 2012).

Acknowledgments. This study was funded through support from the SMAP Science Definition team and the NASA program on the Science of Terra and Aqua. Computing was supported by the NASA High End Computing Program.

\section{REFERENCES}

Bartsch, A., D. Sabel, W. Wagner, and S.-E. Park, 2011: Considerations for derivation and use of soil moisture data from active microwave satellites at high latitudes. Proc. 2011 IEEE Geoscience and Remote Sensing Symp., Vancouver, BC, Canada, IEEE, 3132-3135, doi:10.1109/IGARSS.2011.6049882.
Bateni, S. M., C. Huang, S. A. Margulis, E. Podest, and K. McDonald, 2013: Feasibility of characterizing snowpack and the freeze-thaw state of underlying soil using multifrequency active/passive microwave data. IEEE Trans. Geosci. Remote Sens., 51, 4085-4102, doi:10.1109/TGRS.2012.2229466.

Bingham, A. W., and M. R. Drinkwater, 2000: Recent changes in the microwave scattering properties of the Antarctic Ice Sheet. IEEE Trans. Geosci. Remote Sens., 38, 1810-1820, doi:10.1109/ 36.851765

Black, T. A., and Coauthors, 2000: Increased carbon sequestration by a boreal deciduous forest in years with a warm spring. Geophys. Res. Lett., 27, 1271-1274, doi:10.1029/1999GL011234.

Cherkauer, K. A., L. C. Bowling, and D. P. Lettenmaier, 2003: Variable infiltration capacity cold land process model updates. Global Planet. Change, 38, 151-159, doi:10.1016/ S0921-8181(03)00025-0.

Colliander, A., K. McDonald, R. Zimmermann, R. Schroeder, J. S. Kimball, and E. G. Njoku, 2012: Application of QuikSCAT backscatter to SMAP validation planning: Freeze/thaw state over ALECTRA sites in Alaska from 2000 to 2007. IEEE Trans. Geosci. Remote Sens., 50, 461-468, doi:10.1109/ TGRS.2011.2174368.

Dall, J., S. N. Madsen, K. Keller, and R. Forsberg, 2001: Topography and penetration of the Greenland ice sheet measured with airborne SAR interferometry. Geophys. Res. Lett., 28, 1703-1706, doi:10.1029/2000GL011787.

Dankers, R., E. J. Burke, and J. Price, 2011: Simulation of permafrost and seasonal thaw depth in the JULES land surface scheme. Cryosphere Discuss., 5, 1263-1309, doi:10.5194/ tcd-5-1263-2011.

De Lannoy, G. J. M., R. H. Reichle, K. R. Arsenault, P. R. Houser, S. V. Kumar, N. E. C. Verhoest, and V. R. N. Pauwels, 2012: Multiscale assimilation of Advanced Microwave Scanning Radiometer-EOS snow water equivalent and Moderate Resolution Imaging Spectroradiometer snow cover fraction observations in northern Colorado. Water Resour. Res., 48, W01522, doi:10.1029/2011WR01058.

Ducharne, A., R. D. Koster, M. J. Suarez, M. Stieglitz, and P. Kumar, 2000: A catchment-based approach to modeling land surface processes in a general circulation model: 2. Parameter estimation and model demonstration. J. Geophys. Res., 105, 24 823-24 824, doi:10.1029/2000JD900328.

Entekhabi, D., and Coauthors, 2010: The Soil Moisture Active Passive (SMAP) mission. Proc. IEEE, 98, 704-716, doi:10.1109/ JPROC.2010.2043918.

- , and Coauthors, 2014: SMAP handbook. JPL Publ. JPL 4001567, NASA Jet Propulsion Laboratory, Pasadena, CA, 192 pp. [Available online at http://smap.jpl.nasa.gov/Imperative.]

Frolking, S., K. McDonald, J. Kimball, R. Zimmermann, J. B. Way, and S. W. Running, 1999: Using the space-borne NASA Scatterometer (NSCAT) to determine the frozen and thawed seasons of a boreal landscape. J. Geophys. Res., 104, 27895 27 908, doi:10.1029/1998JD200093.

Goulden, M. L., J. W. Munger, S.-M. Fan, B. C. Daube, and S. C. Wofsy, 1996: Measurements of carbon sequestration by longterm eddy covariance: Methods and a critical evaluation of accuracy. Global Change Biol., 2, 169-182, doi:10.1111/ j.1365-2486.1996.tb00070.x.

Grippa, M., L. Kergoat, T. Le Toan, N. M. Mognard, N. Delbart, J. L'Hermitte, and S. M. Vicente-Serrano, 2005: The impact of snow depth and snowmelt on the vegetation variability over central Siberia. Geophys. Res. Lett., 32, L21412, doi:10.1029/ 2005 GL024286. 
Kane, D. L., L. D. Hinzman, R. E. Gieck, J. P. McNamara, E. Youcha, and J. A. Oatley, 2008: Contrasting extreme runoff events in areas of continuous permafrost, Arctic Alaska. $\mathrm{Hy}$ drol. Res., 39, 287-298, doi:10.2166/nh.2008.005.

Kim, Y., J. S. Kimball, K. C. McDonald, and J. Glassy, 2011: Developing a global data record of daily landscape freeze/thaw status using satellite passive microwave remote sensing. IEEE Trans. Geosci. Remote Sens., 49, 949-960, doi:10.1109/ TGRS.2010.2070515.

, _ , K. Zhang, and K. C. McDonald, 2012: Satellite detection of increasing Northern Hemisphere non-frozen seasons from 1979 to 2008: Implications for regional vegetation growth. Remote Sens. Environ., 121, 472-487, doi:10.1016/ j.rse.2012.02.014.

Kimball, J. S., K. C. McDonald, A. R. Keyser, S. Frolking, and S. W. Running, 2001: Application of the NASA Scatterometer (NSCAT) for determining the daily frozen and nonfrozen landscape of Alaska. Remote Sens. Environ., 75, 113-126, doi:10.1016/S0034-4257(00)00160-7.

, - - S. Frolking, and S. W. Running, 2004a: Radar remote sensing of the spring thaw transition across a boreal landscape. Remote Sens. Environ., 89, 163-175, doi:10.1016/j.rse.2002.06.004.

,-- , S. W. Running, and S. E. Frolking, 2004b: Satellite radar remote sensing of seasonal growing seasons for boreal and subalpine evergreen forests. Remote Sens. Environ., 90, 243-258, doi:10.1016/j.rse.2004.01.002.

, - - and M. Zhao, 2006: Spring thaw and its effect on terrestrial vegetation productivity in the western Arctic observed from satellite microwave and optical remote sensing. Earth Interact., 10, doi:10.1175/EI187.1.

—, R. Reichle, P. O'Neill, K. McDonald, and E. Njoku, 2012: SMAP level 4 carbon data product (L4_C). Algorithm Theoretical Basis Doc., Jet Propulsion Laboratory, Pasadena, CA, 73 pp. [Available online at http://nsidc.org/data/smap/pdfs/ atbds/14_c_initrel_v1_filt_10.pdf.]

Koster, R. D., M. J. Suarez, A. Ducharne, M. Stieglitz, and P. Kumar, 2000: A catchment-based approach to modeling land surface processes in a general circulation model: 1 . Model structure. J. Geophys. Res., 105, 24809-24822, doi:10.1029/2000JD900327.

Koven, C., P. Friedlingstein, P. Ciais, D. Khvorostyanov, G. Krinner, and C. Tarnocai, 2009: On the formation of highlatitude soil carbon stocks: Effects of cryoturbation and insulation by organic matter in a land surface model. Geophys. Res. Lett., 36, L21501, doi:10.1029/2009GL040150.

Lawrence, D. M., A. G. Slater, V. E. Romanovsky, and D. J. Nicolsky, 2008: Sensitivity of a model projection of near-surface permafrost degradation to soil column depth and representation of soil organic matter. J. Geophys. Res., 113, F02011, doi:10.1029/ 2007JF000883.

- , K. W. Oleson, M. G. Flanner, C. G. Fletcher, P. J. Lawrence, S. Levis, S. C. Swenson, and G. B. Bonan, 2012: The CCSM4 land simulation, 1850-2005: Assessment of surface climate and new capabilities. J. Climate, 25, 2240-2260, doi:10.1175/ JCLI-D-11-00103.1.

Lynch-Stieglitz, M., 1994: The development and validation of a simple snow model for the GISS GCM. J. Climate, 7, 1842-1855, doi:10.1175/1520-0442(1994)007<1842:TDAVOA >2.0.CO;2.

Mätzler, C., and E. Schanda, 1984: Snow mapping with active microwave sensors. Remote Sens., 5, 409-422, doi:10.1080/ 01431168408948816.

McDonald, K., J. S. Kimball, E. Njoku, R. Zimmermann, and M. Zhao, 2004: Variability in springtime thaw in the terrestrial high latitudes: Monitoring a major control on the biospheric assimilation of atmospheric $\mathrm{CO}_{2}$ with spaceborne microwave remote sensing. Earth Interact., 8, doi:10.1175/1087-3562(2004)8<1: VISTIT $>2.0 . \mathrm{CO} ; 2$

$\longrightarrow$, E. Podest, S. Dunbar, E. Njoku, and J. Kimball, 2012: SMAP level 3 radar freeze/thaw data product. Algorithm Theoretical Basis Doc., Jet Propulsion Laboratory, Pasadena, CA, 32 pp. [Available online at http:/nsidc.org/data/smap/pdfs/atbds/ 13_ft_a_initrel_v1_7.pdf.]

Mironov, V. L., R. D. De Roo, and I. V. Savin, 2010: Temperaturedependable microwave dielectric model for an arctic soil. IEEE Trans. Geosci. Remote Sens., 48, 2544-2556, doi:10.1109/ TGRS.2010.2040034.

Nemani, R. R., C. D. Keeling, H. Hashimoto, W. M. Jolly, S. C. Piper, C. J. Tucker, R. B. Myneni, and S. W. Running, 2003: Climate-driven increases in global terrestrial net primary production from 1982 to 1999 . Science, 300,1560-1563, doi:10.1126 science 1082750 .

Randerson, J. T., C. B. Field, I. Y. Fung, and P. P. Tans, 1999 Increases in early season ecosystem uptake explain recent changes in the seasonal cycle of atmospheric $\mathrm{CO}_{2}$ at high northern latitudes. Geophys. Res. Lett., 26, 2765-2768, doi:10.1029/ 1999GL900500.

Rautiainen, K., J. Lemmetyinen, J. Pulliainen, J. Vehviläinen, M. Drusch, A. Kontu, J. Kainulainen, and J. Seppänen, 2012: L-band radiometer observations of soil processes in boreal and subarctic environments. IEEE Trans. Geosci. Remote Sens., 50, 1483-1497, doi:10.1109/TGRS.2011.2167755.

— passive microwave observations. Remote Sens. Environ., 147, 206-218, doi:10.1016/j.rse.2014.03.007.

Rawlins, M. A., K. C. McDonald, S. Frolking, R. B. Lammers, M. Fahnestock, J. S. Kimball, and C. J. Vörösmarty, 2005: Remote sensing of snow thaw at the pan-Arctic scale using the SeaWinds scatterometer. J. Hydrol., 312, 294-311, doi:10.1016/ j.jhydrol.2004.12.018.

- D. J. Nicolsky, K. C. McDonald, and V. E. Romanovsky, 2013: Simulating soil freeze/thaw dynamics with an improved pan-Arctic water balance model. J. Adv. Model. Earth Syst., 5, 659-675, doi:10.1002/jame.20045.

Reichle, R. H., 2012: The MERRA-Land data product (version 1.2). GMAO Office Note 3 , NASA GSFC, Greenbelt, MD $38 \mathrm{pp}$. [Available at https:/gmao.gsfc.nasa.gov/pubs/docs/ Reichle541.pdf.]

- , S. V. Kumar, S. P. P. Mahanama, R. D. Koster, and Q. Liu, 2010: Assimilation of satellite-derived skin temperature observations into land surface models. J. Hydrometeor., 11, 1103-1122, doi:10.1175/2010JHM1262.1.

—, R. D. Koster, G. J. De Lannoy, B. A. Forman, Q. Liu, S. P. Mahanama, and A. Touré, 2011: Assessment and enhancement of MERRA land surface hydrology estimates. J. Climate, 24, 6322-6338, doi:10.1175/JCLI-D-10-05033.1.

—, G. J. M. De Lannoy, B. A. Forman, C. S. Draper, and Q. Liu, 2014: Connecting satellite observations with water cycle variables through land data assimilation: Examples using the NASA GEOS-5 LDAS. Surv. Geophys., 35, 577-606, doi:10.1007/ s10712-013-9220-8.

Rienecker, M. M., and Coauthors, 2011: MERRA: NASA's ModernEra Retrospective Analysis for Research and Applications. J. Climate, 24, 3624-3648, doi:10.1175/JCLI-D-11-00015.1.

Rignot, E., K. Echelmeyer, and W. Krabill, 2001: Penetration depth of interferometric synthetic-aperture radar signals in snow and ice. Geophys. Res. Lett., 28, 3501-3504, doi:10.1029/ 2000 GL012484. 
Rodell, M., and Coauthors, 2004: The Global Land Data Assimilation System. Bull. Amer. Meteor. Soc., 85, 381-394, doi:10.1175/ BAMS-85-3-381.

, and P. R. Houser, 2004: Updating a land surface model with MODIS-derived snow cover. J. Hydrometeor., 5, 1064-1075, doi:10.1175/JHM-395.1.

Smith, N. V., S. S. Saatchi, and J. T. Randerson, 2004: Trends in high northern latitude soil freeze and thaw cycles from 1988 to 2002. J. Geophys. Res., 109, D12101, doi:10.1029/ 2003JD004472.

Wang, L., C. Derksen, and R. Brown, 2013: Recent changes in pan-Arctic melt onset from satellite passive microwave measurements. Geophys. Res. Lett., 40, 522-528, doi:10.1002/ grl.50098.
Zhang, K., J. S. Kimball, Y. Kim, and K. C. McDonald, 2011: Changing freeze-thaw seasons in northern high latitudes and associated influences on evapotranspiration. Hydrol. Processes, 25, 4142-4151, doi:10.1002/hyp.8350.

Zhang, T., and R. L. Armstrong, 2001: Soil freeze/thaw cycles over snow-free land detected by passive microwave remote sensing. Geophys. Res. Lett., 28, 763-766, doi:10.1029/2000GL011952.

Zhao, T., L. Zhang, L. Jiang, S. Zhao, L. Chai, and R. Jin, 2011: A new soil freeze/thaw discriminant algorithm using AMSR-E passive microwave imagery. Hydrol. Processes, 25, 1704-1716, doi:10.1002/hyp.7930.

Zuerndorfer, B., and A. W. England, 1992: Radio brightness decision criteria for freeze/thaw boundaries. IEEE Trans. Geosci. Remote Sens., 30, 89-102, doi:10.1109/36.124219. 